\title{
The Development of the Flower and Embryo in Lilaea subulata, H.B.K.
}

\author{
BY \\ D. H. CAMPBELL, PH.D., \\ Professor of Botany in the Stanford University, California, U.S.A.
}

\section{With Plates I-III.}

THE genus Lilaea is a peculiar monotypic one, the single species, $L$. subulata, being widely distributed through the western part of the American continent. According to Hieronymus ${ }^{1}$, who has made the most careful study of the plant, its range is from Oregon, throughout the coast region of California and Mexico, into South America. In the latter it has been collected in Colombia, Chile, Argentina, and Uruguay, and has been found at various elevations, from sea-level to a height of 3,000 metres.

There is much diversity of opinion as to the systematic position of the plant. In Engler and Prantl's Natürliche Pflanzenfamilien ${ }^{2}$, it is classed with the Juncaginaceae; but Schumann ${ }^{3}$ is inclined to consider it as representing a special family, Lilaeaceae, proposed originally by Hieronymus, and

1 Engler and Prantl, Die Natürlichen Pflanzenfamilien, II, I, p. 225.

Loc. cit.

- Morphologische Studien, Leipzig, 1892, Heft I, p. 187.

[Annals of Botany, Vol. XII. No. XLV. March, 1898.] 


\section{Campbell.-The Development of the Flower and}

this probably is more in accordance with the peculiar characters of the plant.

Our knowledge of the morphology of the plant is mainly derived from the elaborate monograph of Hieronymus ${ }^{1}$, which proposed to give a very full account of the morphology, but was unfortunately left incomplete. Schumann ${ }^{2}$ has given some details as to the relation of the flower to the axis of the plant, but these simply confirm the earlier observations of Hieronymus. Beyond the work of these observers, so far as the writer knows, the plant has been described only in a superficial way.

The writer has been engaged for some time upon a study of the flower and embryo in a number of the simpler Monocotyledons, and among the forms which have engaged his attention is Lilaea, which is common in the region about San Francisco Bay. The results of these studies are given in the following pages.

The material upon which these were made was for the most part collected in the neighbourhood of Stanford University, where the plant is a common one. In this neighbourhood the plant grows either in shallow water, or completely exposed upon the mud. More rarely the plant is completely. submerged except the flowers. It is an annual, germinating with the advent of the winter-rains, and flowering within a few weeks of germination. Flowers continue to form as long as the plant grows, but the plant is finally killed by the drying up of the mud in which it is rooted. The ripened fruits remain in the dried mud during the summer and autumn, and germinate as soon as the rains have soaked the ground.

Most of the plants collected by the writer grew in the tenacious black clay ('adobe') characteristic of much of the land in the immediate vicinity of the University. The favourite localities for the plant were depressions in the fields

\footnotetext{
1 Monografla de Lilaea: Actas de la Academia Nacional de Ciencias en Cordoba. Buenos Aireg, 1892.

Lac cit.
} 
where the water collected and formed shallow pools. These seemed to offer the most favourable conditions for the germination of the seeds. Of course the time of germination varies with the time of the rains, but in January, 1897 , the plants were found in various stages of germination; and in 1895 , an unusually rainy winter, the plants were well in flower in February.

The general aspect of the plant is curiously like Isoetes, the subulate leaves forming dense tufts from the short, bulb-like stem. The leaves are strictly two-ranked, and numerous white unbranched roots fasten the plant into the soft mud. The arrangement of the leaves and roots, as well as that of the flowers, has been given in detail by Hieronymus ${ }^{1}$, and will be discussed only briefly here. The flowers are exceedingly simple in structure, but nevertheless show much variation, at least in the pistillate flowers which exhibit heterostylism in a very remarkable degree.

After the young plant has produced several-usually from five to seven-leaves, the axis becomes transformed into a shaft bearing a spike of flowers; while in the axil of the last-formed leaf is formed a shoot which, after producing a single leaf, is transformed also into an inflorescence like that derived from the original stem-apex, and in the axil of the leaf is formed another shoot which behaves in the same way. Thus the branching of the plant is sympodial. In addition to the flowers borne upon the spike, there are usually found two close to the base of the shaft but not outgrowths of it. These basal flowers are always pistillate, and are distinguished by their extremely long styles, which may reach a length of several centimetres (14 c. in some cases, according to Hieronymus).

The lowest flowers of the spike, where these are pistillate, are destitute of any subtending bract or leaf, but the other flowers are borne in the axil of a small bract. Of the pistillate flowers borne upon the spike, the lower ones are

1 Monografia de Lilaea.

B 2 


\section{Campbell.-The Development of the Flower and}

intermediate in character between the very long-styled basal flowers and the very short-styled flowers near the apex, in which the stigma is nearly or quite sessile.

In the axils of all the foliage-leaves are borne a number of the delicate scales (squamulae intravaginales) so characteristic of most of the simple aquatic Monocotyledons.

The histology of the vegetative organs of the plant has been worked out very carefully by Hieronymus: but unfortunately only the roots and leaves are fully described, his memoir ending abruptly before the description of the stem was completed. Numerous beautiful and accurate figures of the histology are however given, which make it possible to follow out most of the structural details.

In common with other aquatics, the leaves contain large lacunae, which here are irregularly arranged, and separated from one another by single layers of cells. There are numerous vascular bundles of the ordinary collateral type. The number of these bundles varies much with the size of the leaves. Hieronymus ${ }^{1}$ states that in the most vigorous leaves he studied there were sometimes twenty-one. Of these one occupies a nearly median position, near the outer side of the leaf, and he considers this to represent a midrib.

The epidermis of the leaves shows the usual elongated cells of similar leaves, and stomata are found, characterized by the presence of accessory cells not unlike those of many Grasses.

The author's own observations were based mainly upon series of microtome-sections. The material was fixed with chromic acid, and, after thorough washing, stained in toto with Czokor's alum-cochineal, and afterwards stained on the slide with alcoholic Bismark-brown. For the study of the embryo-sac, safranin and haematoxylin were also used to some extent as nuclear stains.

1 Monografía de Lilaea, p. 39. 


\section{General Morphology of the Young Plant.}

In Fig. 2 is shown a median longitudinal section of a young plant with the apex prolonged into the first floral spike $(x)$, and the two basal pistillate flowers (q) already formed. The stem itself is very short, and made up of nearly uniform parenchymatous tissue, which is traversed by the vascular bundles running into the leaves and the young inflorescence; short bundles are also given off to the basal flowers. The arrangement of the parts in a more advanced stage can be seen in Fig. $I$, where several secondary inflorescences have formed.

The number of roots is very large. According to Hieronymus, there is usually a secondary root on each side of the cotyledon, and the number formed from the later nodes varies with the size of the plant. No special study was made of the origin of these secondary roots, beyond noting that they form deep down within the tissue of the stem near the base of the leaves and close to a vascular bundle. They are consequently well developed before they finally break through the overlying tissues. The structure of the roots and the arrangement of the primary tissues are only briefly treated by Hieronymus ${ }^{1}$, but he gives very accurate figures which make it perfectly clear that the arrangement of the tissues is that of the typical Monocotyledons, and these points have been confirmed by the writer. The very distinct plerome-cylinder, showing about five rows of cells in longitudinal section, is separated from the root-cap by a group of cells which are the common initials for epidermis and cortex. There is a separate group of initials for the root-cap. Hieronymus' figures would indicate a single initial cell for the plerome, but he has not stated this in the text; my own preparations make this seem not improbable, but it was not possible to decide the matter positively.

The number of squamulae is variable, and they do not

1 Monografia de Lilaca, PL. IV. 


\section{Campbell.-The Development of the Flower and}

differ in any marked degree from similar structures in other Monocotyledons. The cells have delicate walls, and densely granular protoplasm with a distinct nucleus. The whole aspect of the cells is that of secretory ones, but this point was not further investigated.

\section{DeVElopment OF THE INFLORESCENCE.}

The primary inflorescence, as we have seen, is the direct prolongation of the original stem-apex of the young plant, and the later ones have a similar relation to the secondary shoots, which first produce a single leaf and then elongate at once to form the inflorescence. The apex gives rise to a stamen, while the other flowers-except the basal pistillate ones-are formed as lateral appendages. The lowermost flowers are usually female, with a moderately long style, and without any subtending bract; but the other flowers have below them a small bract, which probably is the equivalent of the leaf at the base of the main shoots.

The arrangement of the flowers upon the inflorescence shows a good deal of variation. The commonest arrangement upon well-developed spikes is that in which the lowest flowers are pistillate, the central ones hermaphrodite-or probably a secondary inflorescence made up of two flowers, male and female, - and those at the apex are staminate only. The writer has, however, seen cases where all the flowers were staminate, each stamen being subtended by a bract; and Hieronymus ${ }^{2}$ figures a specimen where only female flowers were developed. In the latter case, to judge from his figures, all the flowers were destitute of bracts. Where a single flower only is produced in the axil of the bract, the primordium or young shoot is transformed directly into the carpel or stamen, as the case may be; but when the carpel and stamen are formed together, there is a division of the primordium into two equal parts, and this appears

1 Monografia de Lilaea, Pl. I, Fig. 6. 
to be a true dichotomy like that which occurs in Naias previous to the formation of the flower.

In Fig. 3 is shown a median section through the foral complex from the middle region of a very young inflorescence. The arrangement of the organs suggests very strongly that found in Naias at a similar stage of development ${ }^{1}$. This consists of two nearly equal superimposed protuberances, respectively $\delta$ and $q$, which apparently are formed by a true dichotomy of a common primordium. The latter has below it a very slightly projecting ridge, $l$, the rudiment of the subtending bract found in the older flowers. Of the two parts into which the primordium is divided, the upper is bluntly conical in form, the lower more pointed when seen in section, but really considerably flattened in the plane of division of the primordium. The upper prominence is the young carpel, the lower the stamen. Each of these structures, from analogy with the very similar ones in Naias and Zannichellia, may be considered as representing shoots of equal morphological value, resulting from the dichotomy of a common primordium. If this view is accepted, both the stamen and carpel must be considered as truly axial structures.

The young primordium is composed of nearly similar cells, which are arranged in the manner characteristic of the stemapex of the Angiosperms. There is a definite dermatogen below which is a pretty clearly defined layer of periblem which separates the dermatogen from the central pleromemass. This arrangement is especially clear in the staminal rudiment.

\section{The Male Flower.}

The development of the single stamen which constitutes the male flower, whether formed alone in the axil of the bract, or secondarily from the dichotomy of the axillary primordium, follows the same line of development:

1 Magnus, Beiträge zur Kenntniss der Gattung Naias; Berlin, 187o. Campbell, A Morphological Study of Naias and Zanoichellia, Proc. Califorpia Academy of Sciences, 1897 . 


\section{Campbell.-The Development of the Flower and}

The very young stamen, cut parallel to its broad face (Fig. 5), is broadly conical, slightly constricted at the base, thus indicating the differentiation of anther and filament. In this stage it is composed of nearly isodiametric parenchyma, but shows the definite divisions of the tissues into dermatogen, periblem, and plerome, referred to in connexion with the original primordium. The plerome in this view has a broadly conical form, with two lateral outgrowths marking the position of the future loculi. A cross-section of a similar stage shows that there are really four of these.

A cross-section of a somewhat older stage is shown in Fig. 7. While there is in general the same arrangement of the tissues seen in the younger stamen, the loculi are more clearly defined. The two upon the outer side are somewhat broader than the others, and between them there is a small sterile lobe. Each loculus shows much the same arrangement of the tissues as the whole of the young staminal rudiment, and the origin of the sporogenous tissue is plainly traceable in all cases to the plerome. The latter is usually well defined, and forms a conical mass, usually three or four cells wide at the base, and narrowing above. The periblem, which at first is but one cell thick, later, by the formation of periclinal walls, becomes thicker, and finally the limits between it and the plerome are no longer distinguishable. In cross-section at this stage, there may be seen two vascular bundles near the base of the inner loculi. The exact origin of the sporogenous cells is difficult to trace, but there seems no question that they originate from the outer cells of the plerome, and that the archesporium is not of hypodermal origin as is usually the case. In this respect Lilaea agrees with Naias flexilis, and probably also with Zannichellia, although in the latter the question is not quite clear ${ }^{1}$.

At first the young sporogenous cells are not readily distinguishable from those surrounding them, and it is quite impossible to trace them back certainly to the division of

\footnotetext{
1 Campbell, l. c., pp. I3 and 41 .
} 
a single primary archesporial cell ; indeed it is quite improbable that they all originate from a common mother-cell. As they become older, however, they become noticeably larger than their neighbours, and show the usual dense contents and large nuclei (Figs. 9, 10). However, even in these stages the transition from genuine sporogenous tissue to the tapetal cells is somewhat gradual. The latter are derived mainly from the periblem, but functionally, at least, some of the plerome-cells must be regarded as tapetal.

As the stamen grows, the four masses of sporogenous tissue become very clearly defined. Each group of sporogenous cells is surrounded by about three, or in places four or five, layers of cells which separate it from the epidermis. The cells, which at first are much alike, later show considerable differentiation.

Fig. Io shows a longitudinal section of a loculus shortly before the separation of the sporogenous cells. The epidermal cells are now much elongated, but are very little deeper than they were in the very young stamen. Under the epidermis is a layer of somewhat swollen cells which, with the epidermis, persists as the wall of the mature loculus. Within this second layer is a third one, composed of very much compressed cells $(c)$, which with a fourth layer $(d)$ make up the tapetum. The layer $d$ has larger cells which resemble the sporogenous cells in the character of their contents.

The sporogenous cells $(s p$.) have the usual characters of such cells. They are thin-walled, isodiametric, with abundant granular cytoplasm and large nuclei. The nucleoli are conspicuous and the chromatin abundant. The nucleus, in material fixed with chromic acid, usually shows a conspicuous areola about the nucleolus. On the inner side of the loculus especially, the tapetal cells encroach upon the sporogenous area, and there are cells which are intermediate in character between the perfect sporogenous cells and those of the tapetum. These are probably to be considered as potentially sporogenous cells which do not, however, develop into spores, but become broken down and serve, like the true tapetal cells, 
to nourish the developing spores. A similar disintegration of part of the sporogenous tissue has been observed by the writer in Zannichellia, and is very much like what takes place in Equisetum.

The sporogenous cells after separation are imbedded in a nucleated mass of protoplasm derived from the tapetal cells and the imperfect sporogenous ones (Fig. II). As in most Monocotyledons the spores are of the bilateral type, i.e. there are two complete successive cell-divisions of the pollenmother-cell. The spores do not long remain united in tetrads, but separate completely and assume an almost perfectly globular form. The young spore contains but a single nucleus, but there is later a division into two cells of very unequal size. The ripe spore (Figs. 12-14) shows a double wall, the outer one marked with fine reticulations, the inner one being the delicate endospore. The spore before maturity contains very little granular contents, but these increase rapidly as the spore ripens. The exact nature of the reserve substances in the ripe spore was not investigated. The structure of the anther-wall (Fig. 13 ) is of the usual type.

The nuclei of the two cells in the germinating spore are very different in appearance. That of the large vegetative cell (Fig. I $2, v$ ) is large, with but little chromatin and a large nucleolus. The nucleus of the small generative or antheridial cell $(g)$, on the other hand, is small, staining strongly and having an inconspicuous nucleolus. No indication of a further division of the antheridial cell, such as occurs in many Monocotyledons, was seen, although it is almost certain that this does occur in the pollen-tube after germination.

\section{The Female Flower.}

The homologies of the two pistillate flowers which usually occur near the base of the shaft of the inflorescence are not entirely clear, but they probably represent shoots of the same nature as the innovations which occur in the larger plants, in addition to the shoots formed in the axils of the leaves. 
These basal flowers arise on either side of the floral axis (Fig. $2, q$ ), and are very early recognizable. In these the young ovule is already evident as a slender prominence whose axial nature is unmistakable, and it represents, with little question, the end of the metamorphosed shoot which constitutes the flower. Sometimes, and perhaps always, the flower has at its base a small bract, in which respect it differs from the pistillate flowers of the spike, which are destitute of a similar subtending bract. The central ovilar rudiment (Fig. I 5, 0) is enclosed by a cup-shaped envelope arising from the growth of the surrounding tissue, and this body, the carpel, which is formed precisely as in Naias, is probably to be considered as a foliar member. It is of equal height on all sides, and shows no evident dorsi-ventral structure.

The pistillate flowers upon the spike are of two kinds, those which stand alone at the base of the spike, and those which are associated with the male flowers. The former are longer-styled, and are in this respect intermediate between the extremely long-styled ones and the upper short-styled ones. In the lower flowers of the spike, the whole primordium is transformed into the flower; in the upper ones, as we have seen, there is first a dichotomy of the primordium, only one member of which forms the pistillate flower. In both cases, however, the flower is to be looked upon as a transformed shoot, whose apex develops into the ovule, while the carpel represents a foliar appendage of the floral axis.

In a section of the young pistillate flower from the spike (Fig. 17), the ovule is not nearly so conspicuous as in the long-styled flowers. Here the young carpel is developed much more strongly upon the inner side, while upon the outer side it is not clearly distinguishable from the ovular rudiment, which is much less noticeable at this stage than it is in the long-styled flowers. The ovule is not so slender as that of the basal flowers, and more rounded at the end; but by comparing it with a somewhat older one (Fig. I9), it is evident that here too the ovule is the transformed apex of the shoot. The young short-styled flower, at this stage, is 


\section{Campbell.-The Development of the Flower and}

very much like the corresponding stage in Zannichellia; indeed the whole development of the flower is very much like that of the latter.

In the long-styled flower, the slender ovular rudiment soon shows a broader and somewhat pointed form (Fig. I 6 ). The pointed appearance is due to a stronger growth at this place, by which the original apex is forced over to one side, this being the first indication of the anatropous form of the older ovule. In the short-styled flower, the young ovule (Figs. I7, $19,0)$ is much blunter from the first, but here also the original apex is soon bent over by the excessive growth upon the outer side of the young ovule. In both forms of flowers, the growth of the carpel is rapid; it soon grows up beyond the top of the ovule, and the margins, which at first are quite free, so that the carpel forms an open cup, approach and finally meet, the ovary-cavity thus becoming completely closed. The carpel is closely appressed to the ovule, and its upper part is extended into the tubular style, the final development of the latter varying much as we have already indicated. The young style is traversed by a narrow open canal, but this later becomes entirely closed by the cohesion of the cells lining it. In the long-styled flower, the style and stigma are perfectly symmetrical; but in the short-styled one, the stronger development of the carpel upon the inner side of the young flower persists, so that the stigma is much more strongly developed upon this side (Fig. 25).

As the ovule develops, the much stronger growth on one side forces the original apex over until it assumes nearly a horizontal position (Figs. 18, 20), and finally it becomes perfectly anatropous (Fig. 25). The first integument becomes evident at a very early period, and forms a shallow cupshaped structure, more strongly developed on the upper side of the ovule (Figs. 18, 20, in.). Not long after this, the second (outer) integument is differentiated, but this is fully developed only upon the outer free side of the ovule (Fig. 2I, $i n^{2}$ ); while upon the inner side, which is in contact with the funiculus, it is imperfect. The inner integument is 
composed, for the most part, of two layers of cells and soon reaches to the top of the nucellus, and later closes over it to form the micropyle. The outer integument remains less developed than the inner one, and barely reaches to its level.

\section{The Style and Stigma.}

While there are some minor differences in the development of the style in the long- and short-styled flowers, the structure of the fully developed parts is essentially the same. At an early period in the growth of the flower, the free superficial cells of the upper margins of the carpel become enlarged into papillae (Fig. 25, st.), which later reach a great size, and are distinguished also by very dense granular cytoplasm and large nuclei. When the pistil is mature, they form a dense tuft of conspicuous stigmatic hairs.

The narrow canal, which is present in the very young style, soon becomes completely obliterated by the coalescence of the cells forming its walls. These cells, which are the continuation of the epidermal cells which form the stigmatic papillae, much resemble the latter in the character of their contents, although the nuclei are smaller. There are, however, transitional forms in the upper part of the style. Occasional indications of more than one nucleus in these cells were seen, but the matter was not further investigated. These cells together form a very distinct strand of conducting-tissue, which in cross-section is oval, and very clearly defined.

The arrangement of the tissues in the style may be readily seen by comparing cross and longitudinal sections. The epidermis is composed of cells with a thickened outer wall, and within this are several layers of loose parenchyma. In the sections examined there were three vascular bundles, but whether this number is constant cannot now be stated. The bundles were of the usual collateral type with a few annular and spiral tracheids in the xylem. These bundles were separated from the central cylinder of conducting-tissue by 


\section{4 Campbell.-The Development of the Flower and}

several layers of more compact parenchyma than that lying between the bundles and the epidermis.

The ovule fills the ovarian cavity almost completely, and there is no development of conducting papillae such as occur in Naias, either at the top of the ovary where the conducting tissue of the style terminates, or at the base of the funiculus near the micropyle. This may be accounted for by the fact that a pollen-tube which has reached the ovary can hardly fail to reach the micropyle, as its course along the wall would almost certainly bring it to the opening of the ovule.

\section{THE EMBRIO-SAC.}

Unfortunately, not a sufficient number of specimens of the earlier stages of the embryo-sac were found to make it certain just how uniform the course of development is. With few exceptions there was nothing to indicate any marked departure from the ordinary type. In the earliest stage in which the archesporial cells could be recognized with certainty, there were two cells, evidently the product of the division of a primary hypodermal cell (Fig. 19). The outer of them was the larger, and is probably to be considered the real archesporium, and from it is apparently next cut off the primary tapetal cell (Fig. $18, t$ ). There is thus formed a row of three cells in the axis of the nucellus. The form of the primary tapetal cell was quite different in different specimens examined (Figs. 18,20 ), but in all cases it undergoes repeated divisions so that the sporogenous cell becomes more deeply sunk in the nucellus (Fig. 22).

The' further history of the sporogenous cell must also be left somewhat incomplete, owing to the small number of satisfactory preparations of the next stage. It is extremely unlikely that the primary sporogenous cell ever develops at once into the embryo-sac, although such a form as that shown in Fig. 21 might possibly be so interpreted. In somewhat later stages (Fig. 22) there were found two or three cells derived from transverse divisions of the primary sporo- 
genous cell, one of which by its subsequent growth destroys the others, and becomes the embryo-sac. In the case figured the lower cell already shows signs of disintegration, while in the upper one it is difficult to say whether we have the young embryo-sac showing the first nuclear division, or what seems more likely, from a comparison with other more advanced stages, the second division of the sporogenous cell, with a suppression of the cell-wall. In other cases where the young embryo-sac was found with two nuclei, it was much larger, and there were the remains of one, and in some cases of two sporogenous cells above it. Whether in any instances there are four complete sporogenous cells formed can only be determined by further investigations.

After it is once formed, the growth of the embryo-sac proceeds rapidly and the other sporogenous cells are destroyed. The youngest stages at which the embryo-sac could certainly be identified, already showed two nuclei. The cytoplasm did not fill the cell, but there was a large ventral vacuole. Near each end was a conspicuous but not very large nucleus, surrounded by a mass of granular protoplasm. The actual divisions of these nuclei were not seen, but there is no reason to suppose that they differ from other similar ones. As usual the four nuclei derived from each occupy either end of the embryo-sac. Those of the upper end are perhaps a little larger than those of the antipodal region, but the difference is very slight, and perhaps not constant. The nuclei are usually distinct with a single large nucleolus. The granular cytoplasm is now confined to a very thin layer at the sides of the embryo-sac, but is more abundant at the ends where the nuclei are situated. The remains of the sister-cell (or cells ?) of the embryo-sac are still evident as a structureless mass lying above it (Figs. 24, 26).

There now begins the differentiation of the antipodal cells and egg-apparatus. The former, which are later very conspicuous, become invested with evident membranes, probably of cellulose, while the two synergidae and the egg soon become easily recognizable at the upper end. These are 


\section{I6 Campbell. - The Development of the Flower and}

distinct and bounded by a well-marked protoplasmic membrane. The two polar nuclei move toward the centre of the sac, where they finally fuse. There is usually no appreciable difference in the size or structure of the two, in which respect Lilaea agrees with Naias and Zannichellia. In his recent paper on the development of Sagittaria variabilis, Schaffner states ${ }^{1}$ that the upper polar nucleus is by far the largest nucleus of the embryo-sac, and in the case figured in Fig. 24 the upper polar nucleus is slightly larger, but this is probably not constant.

The embryo-sac increases rapidly in size after the formation of the egg-apparatus and antipodal cells, and with this increase in size there is a change in the various nuclei, as well as marked growth in both the antipodal cells and the eggapparatus. The former increase very much in size, and are usually arranged in a manner which often strongly suggests the arrangement of the cells of the egg-apparatus. The uppermost cell projects strongly into the cavity of the embryo-sac, and its nucleus becomes decidedly larger than those of the two lower cells (Fig. 28). In all of the cells the protoplasm is very granular, and there are often aggregations which stain strongly, and look almost like nuclei. The nuclei stain readily, and possess a single large nucleolus.

In the upper part of the embryo-sac the three nuclei of the egg-apparatus, which at first were nearly alike, soon show a decided difference in appearance. The two nearest the apex of the sac, the nuclei of the synergidae, increase very little in size, but remain clearly defined. The lower, or eggnucleus, however, becomes many times larger than at first. The polar nuclei also increase very much in size, and the endosperm-nucleus resulting from the fusion (Fig. 27, en.) is the largest of all the nuclei in the embryo-sac. The synergidae, $s$, have a large vacuole, but the upper part, including the nucleus, is filled with granular protoplasm. The egg-cell extends some distance below the synergidae, and its granular

1 Schaffner, The Life History of Sagittaria variabilis, Bot. Gazette, April, 1897. 
protoplasm is more abundant, but contains numerous vacuoles. The nucleus is, as we have said, much larger than those of the synergidae, and contains more chromatin. The nucleolus is large, and in stained sections shows a vacuolated appearance. The large endosperm-nucleus is lenticular in form and has very little chromatin, but the very large nucleolus stains strongly and is much like that of the egg-cell. In the specimen figured there were two small bodies (cen.) lying near the nucleus which may possibly have been centrospheres; but they were not very conspicuous, and it is doubtful, at least, whether they can really be considered as such. They were not seen associated with the other nuclei in the embryosac, so that it must be considered questionable whether they were really centrospheres or only granules belonging to the cytoplasm.

While nearly all the embryo-sacs examined showed the normal structure just described, evidences of a deviation from this were seen in a few cases. The most marked was the one shown in Fig. 3o. Unfortunately the structure of the lower part of the sac could not be clearly made out, as the series of sections was not complete. In the upper part of the sac, which was blunter than in the normal form, there was an irregular cellular mass, showing imperfect cell-walls. Eight nuclei could be certainly made out, but no trace of the definite egg-apparatus or other special structures usually found in the embryo-sac. Whether in the missing sections there were more nuclei than those seen, cannot be stated, but it is not impossible. Whether there were more than the normal number of nuclei, or not, the filling of the upper part of the sac with a cellular structure is a marked departure from the normal structure. Similar abnormal cases have been observed by the writer in Naias flexilis, Zannichellia palustris, and Sparganium eurycarpum; but otherwise, exceptions of this kind seem to have escaped observation. 


\section{Campbell.-The Development of the Flower and}

\section{Pollination.}

The large stigmatic papillae and the conducting-tissue of the style, which is a continuation of the same epidermal tissue whose cells form the stigmatic papillae, have much the same appearance. The dense granular cytoplasm and large nuclei indicate that it is a secretory tissue, and with little question these cells are mainly concerned in forming the substances which serve to nourish the pollen-tube on its way to the ovary.

The ripe pollen-spore is nearly globular, and its finely reticulate exospore is ruptured by the pollen-tube (Fig. 14). The latter grows along the side of the papilla to which it is closely appressed. The growth of the pollen-tube through the conducting-tissue is not easily followed, and no especial study of this point was made, nor was the actual penetration of the pollen-tube into the ovule studied. There was nothing, however, to indicate anything peculiar in this respect.

One of the synergidae is probably destroyed by the growth of the pollen-tube, but one of these can often be detected even after the first division of the embryo (Fig. $29 b, s$ ).

\section{THE EMBRYo.}

The development of the embryo was studied by Hieronymus, apparently with a good deal of care, and he gives numerous accurate figures of the different stages of development in his monograph. Unfortunately there is no account given in the text, nor is any explanation appended to the plates. On the whole his figures correspond closely to my own preparations.

After the egg becomes invested with its cellulose membrane as a result of fertilization, it elongates and divides, as most other Monocotyledons, by a transverse wall into two cells, a basal suspensor-cell, in contact with the upper end of the embryo-sac, and a terminal embryo-cell, which projects 
into the cavity. The embryo-cell, as in Naias and Zannichellia, alone divides, the suspensor-cell remaining permanently undivided. Schaffner's recent observations on Sagittaria and Alisma ${ }^{1}$ show this to be the case in these forms also, although Hanstein ${ }^{2}$ supposed that the primary suspensor-cell underwent subsequent divisions.

The two cells arising from the first division of the egg in Lilaea are almost equal in size (Fig. 29), and much alike in the character of their cell-contents. With the elongation of the embryo, the free end becomes somewhat enlarged, and a transverse wall is formed in the embryo-cell (Fig. 3 $1, b$ ). The next division, at least in the few cases where this was seen, is in the terminal cell and is nearly vertical (Fig. $3^{2}$ ). Following this is a transverse division in the middle cell, and next a further division, by a vertical wall, of each of the two terminal cells. The young embryo at this stage (Fig. 33) consists of six cells exclusive of the suspensor-the four terminal quadrants, only two of which show in the longitudinal section figured, and two cells between these and the suspensor. The latter has undergone no division, but there is a noticeable increase in the size of the nucleus which later becomes still more marked. In these early divisions of the embryo Lilaea agrees closely with Zannichellia and Naias, from which it differs mainly in the embryo being relatively shorter and the suspensor decidedly smaller. As in other similar embryos, the cells contain large vacuoles, the granular cytoplasm being principally confined to the neighbourhood of the nucleus and the periphery of the cell.

There is no absolute uniformity in the next divisions. It not infrequently happens that the first wall in the terminal cell is oblique, and it is possible that sometimes the second vertical walls may be suppressed. This seems to have been the case in the embryo shown in Fig. $3^{6 .}$ Probably the next wall to form, following the quadrant-division in the terminal cell, is in ordinary cases a median vertical wall in the cell

' Schaffiner, The Embryo-Sac of Alisma Plantago, Bot. Garette, March, I896.

- Sachs, Text-book of Botany, 1882 , p. 589 . 


\section{Campbell.-The Development of the Flower and}

immediately below (Fig. 33), and this is later followed by a quadrant-wall in the same cell. The cell next above the suspensor divides by a varying number of transverse walls into a short row of cells, the uppermost of which undergo quadrant-divisions by vertical walls, much like those described in the cell next the terminal quadrants. The lowermost of the series of cells above the suspensor remains for some time, at least, undivided, but may finally undergo division by vertical walls.

The suspensor-cell may finally become much enlarged, but this takes place at a later period than is usual in Naias or Zannichellia; as in them, the nucleus finally reaches a very large size (Fig. 39).

The later divisions in the terminal cells vary a good deal, and the first division in each quadrant-cell may be either approximately vertical or longitudinal (Figs. $35,37,3^{8}$ ). The second divisions are also more or less variable, but the result of the early divisions is usually the formation of a central group of four cells surrounded by a single layer of peripheral ones. The four inner cells form the primary group of plerome-cells for the cotyledon; while the outer ones, by subsequent periclinal divisions, develop the dermatogen and periblem.

While these divisions have been taking place in the terminal group of cells, a similar separation of a central group of plerome-cells also occurs in the segments lying just below the terminal group (Figs. 35, 37); and later, similar but less regular divisions occur in some or all of the basal segments. The number of these basal segments is usually three, and, as a rule, all of them sooner or later show vertical divisions; but transverse divisions are only found at a later period of development, and then only sparingly, so that the limits of the original segments may be made out for a long time (Fig. 39). Finally the limits become indistinguishable, and it is difficult to tell exactly how far the primary segments contribute to the different members of the older embryo. In this respect Lilaea differs from Naias and Zannichellia, where the relation 
of the members of the embryo to the young segments is quite evident.

Owing to the formation of vertical walls in all of the lower segments, there is usually no secondary suspensor, such as usually occurs in other forms, but the enlarged vesicular primary suspensor-cell is in direct contact with the basal cells of the embryo (Fig. 43).

The whole of the cotyledon, and possibly also the stemapex, is derived from the terminal segment of the young embryo ; but owing to the late period at which the stem-apex is first recognizable, it is impossible to decide positively whether, as in Naias, it originates from the second segment, i. e. the cell immediately below the terminal quadrant-cells, or whether, as in Zannichellia, it is the product of the terminal quadrants (Figs. 40, 41). The cell-divisions in the terminal region proceed with great rapidity, while in the basal segments growth proceeds much more slowly. The embryo in consequence becomes pear-shaped, the lower narrow portion being the product of the basal segments, while the enlarged upper part is derived entirely from the terminal segment.

Fig. 39 shows a nearly median longitudinal section of an embryo where the primary tissue-systems are clearly defined, but the external differentiation is not yet indicated. The central plerome-strand is well marked, and shows in longitudinal section two rows of cells, separated from the dermatogen by the periblem, which is for the most part composed of two layers.

In an older stage (Fig. 40) the plerome-cells have undergone longitudinal divisions, and the periblem, especially in the cotyledon, has become very much more massive, owing to cell-divisions in all directions. Cross-sections of the young embryo are oval in outline (Fig. 44), and in the middle region (c) show a somewhat evident differentiation of the primary tissues, which is not clear in the basal region $(a, b)$.

The first evidence of external differentiation is a slight depression on one side of the embryo, near the base. This marks the position of the stem-apex: but it is difficult to 


\section{Campbell.-The Development of the Flower and}

tell whether it is derived from cells originating from the terminal segment of the embryo, or from the segment immediately below, as at this time the limits of the original segments can no longer be recognized with certainty. From its strictly lateral origin, however, and a comparison with other forms where the origin of the stem-apex is undoubtedly from the second segment, it is probable that in Lilaea the terminal segment gives rise to the cotyledon only, and that the stem is the product of the next segment.

The rapid increase in size in the embryo which now takes place is mainly due to the growth of the cotyledon, while the lower part of the embryo remains short. In the cotyledon the plerome-strand is easily seen (Fig. 4I), but it is much less evident in the basal part of the embryo. The epidermis is well defined in all parts of the embryo.

In cross-sections of the older embryo made through the region of the stem-apex, the latter is seen lying in a shallow indentation formed by the base of the cotyledon, whose margins are beginning to form the sheath which later completely encloses it.

The point in which the embryo of Lilaea differs most markedly from that of other Monocotyledons which have been examined, is the origin of the primary root. This, instead of lying with the apex in direct contact with the suspensor, is decidedly lateral in position. In the earlier stages of the embryo it is impossible to make out clearly the relation of the tissues of the root to the other parts of the embryo. As soon as the root can be recognized as such, its axis is almost coincident with that of the stem (Figs. 4I-43), and forms a marked angle with that of the cotyledon. It was not possible to decide positively, from the sections which were examined, what was the exact origin of the different root-tissues. The plerome is evidently continuous with the original axial plerome-cylinder of the young embryo, and is probably derived from the central cells of the second, and perhaps the third segment ; i. e. it is derived, in part at least, from the same segment as the stem. In the older embryo 
(Fig. 43) the broad plerome-cylinder of the root is conspicuous, and the other tissues at the apex of the root begin to show the arrangement found in the fully developed apex. At this stage in the specimens examined, no single initial cell could be made out for the plerome, whose apex was covered by a single layer of periblem-cells which back of the apex become divided by periclinal walls. Outside were two layers of cells, apparently formed by a periclinal division of the original dermatogen, and these give rise to the root-cap.

In the root of the full-grown embryo, the arrangement of the tissues is exactly like that of the roots of the adult plant. The plerome-cylinder shows about five rows of cells in longitudinal section, the central row being the largest, and probably later forming a central vessel. A single cell, somewhat larger than its neighbours, was seen at the apex of the plerome, and may possibly be a single initial, but this point needs further examination. A single layer of cells lies between the plerome and the root-cap, and this group of initials, by the periclinal division of its segments, gives rise to the epidermis and cortex of the root. The inner of the two layers of cells derived from the primary dermatogen (see Fig. 43) becomes the calyptrogen, and from it arise all the later layers of the root-cap.

As the embryo approaches maturity, a second leaf, much like the cotyledon, is developed opposite it, and later a third one at the base of the cotyledon ${ }^{1}$. In this condition the stem-axis has assumed a nearly vertical position, and with this displacement of the stem-apex there is a corresponding change in the position of the primary root, which comes to lie in nearly the same plane as the cotyledon. Hieronymus does not figure any intermediate conditions between quite young stages and the mature embryo, and to judge from his figures (nothing is given on the subject in the text of his memoir) he apparently supposed that the origin of the root was terminal, as in other Monocotyledons.

\footnotetext{
1 See Hieronymus, Pl. IV, Fig. $4^{2}$.
} 


\section{Campbell.-The Development of the Flower and}

\section{THE ENDOSPERM.}

The formation of the endosperm begins shortly after fertilization. The primary endosperm-nucleus divides in the upper part of the embryo-sac, and the derivative nuclei distribute themselves in the layer of protoplasm lining its wall. The number of nuclei is large, and the protoplasmic layer becomes a good deal thickened, but no cell-divisions were seen in the endosperm. The nuclei are distinct, each with a single conspicuous nucleolus (Fig. 44, a), and vary a good deal in size. The embryo finally fills the embryo-sac completely, and in the mature seed there is no trace of the endosperm.

\section{SUMMARY.}

I. The flowers of Lilaea are of strictly terminal origin, both anther and ovule being formed directly from the transformed apex of the shoot.

2. The sporogenous tissue of the stamen is not hypodermal in its origin, but arises from the plerome, as in Naias and Zannichellia.

3. The ripe pollen-spore has two cells. The generative nucleus remains undivided in the ripe spore.

4. The archesporium of the ovule is hypodermal, and a tapetal cell is cut off from it.

5. The primary sporogenous cell of the ovule divides usually into three, of which the middle one becomes the embryo-sac.

6. The embryo-sac usually develops in the manner typical of the Angiosperms, but there may be a suppression of a definite egg-apparatus, and a formation of cellular tissue in the upper part of the embryo-sac before fertilization. This is probably accompanied by an increase in the number of nuclei, such as has been observed in other low Monocotyledons.

7. The first division of the embryo is the typical one into 
two cells, a basal suspensor-cell which remains permanently undivided, and a terminal embryo-cell.

8. The cotyledon is derived entirely from the terminal one of the primary segments into which the embryo-cell first divides.

9. The stem probably always originates from the second embryonal segment, but this point is still somewhat doubtful. Its position is strongly lateral.

Io. The root is of lateral origin, in this respect differing from other Monocotyledons which have been studied.

II. The root of the mature embryo is entirely like that of the older plant.

\section{CONCLUSIONS.}

From the study made of the development of the flower and embryo of Lilaea, it is clear that it shows resemblances to the other low Monocotyledons which have been studied. The apical origin of the sporangia is very much like that of Naias and Zannichellia, and it is quite probable that this will be found to be the case in other low types, such as Sparganium and the Potamogetonaceae; but further investigations are necessary to determine this.

The origin of the stamen and carpel in cases where they occur together, from the dichotomy of a common primordium, makes it probable that the resulting complex should be considered as a secondary inflorescence composed of two flowers, rather than as an hermaphrodite flower.

While the development of the embryo-sac is normally that of the typical Angiosperms, the occurrence of exceptional cases with a probable multiplication of the nuclei and the development of cellular tissue before fertilization is significant, especially in view of the similar phenomena in Naias, Zannichellia, and Sparganium, and suggests a possible case of reversion to a more primitive condition.

The development of the embryo itself is most remarkable for the peculiar lateral origin of the root, which is quite 


\section{Campbell.-The Development of the Flower and}

different from that in the typical Monocotyledons. Just what the significance of this is, is hard to determine. This lateral position is rather suggestive of the root in Isoetes, and possibly the basal segments of the embryo with the suspensor might be interpreted as equivalent to the foot in the embryo of the Pteridophytes. A study of the embryo in other simple Monocotyledons may yield some further information upon this point.

While it must be admitted that these investigations do not throw much light upon the question of the origin of the simpler Monocotyledons from pteridophytic ancestors, such as Isoetes, it may also be said that there is no further evidence for the view commonly held that they are degenerate forms, descended from more specialized ancestors. There is certainly no evidence that the flowers are derived from any type found among the higher Monocotyledons, and the writer is strongly inclined to believe that the simplicity of the flowers is really primitive. It is hoped that further investigations, which it is proposed to make, may possibly help to elucidate this very interesting subject. 


\title{
EXPLANATION OF FIGURES IN PLATES I, II, AND III.
}

\author{
Illustrating Professor Campbell's Paper on Lilaea subulata.
}

\section{PLATE I.}

Fig. I. Median longitadinal section of a young plant; $\times 40 ; l, l$, leaves; 8. female; $\delta$, male flowers; $s q$, squamulae intravaginales; $i$, lacunae in the leaves.

Fig. 2. A similar section of a younger plant with the primary axis transformed. into the first inflorescence, $x$; lettering as in Fig. 1 .

Fig. 3. Median section through a very young floral complex from the middle region of the inflorescence; $\times 600$ (about); $l$, the subtending bract; $b$, male; \&, female flower.

Fig. 4. A similar section of an older floral complex ; $x$ 100.

Fig. 5. Longitudinal section of the young stamen, showing the arrangement of the primary tissues; $\times 350$.

Fig. 6. A similar section of an older stamen; $\times 100 ; l$, the subtending bract.

Fig. 7. Cross-section of a young stamen, showing the four loculi; s, sterile lobe; $\times 35^{\circ}$.

Fig. 8. A single loculos from another of about the same age as that shown in Fig. $6 ; \times 600$. The limits of the plerome are indicated by a heavy line.

Fig. 9. Cross-section of a laculus showing the young sporogenous tissue; $\times 600$. The sporogenons cells have the nuclei shown.

Fig. 10. Longitudinal section of the anther shortly before the isolation of the sporogenous cells; $\times 600 ; c, d$, the onter tapetal cells; $t$, the cells of the inner tapetum.

Fig. II. Young spore-tetrad imbedded in the nucleated protoplasm derived from the disintegrated tapetal and sterile sporogenons cells.

Fig. 12. Section of a nearly ripe pollen-spore, with the generative cell, $g$, and the nacleas, $v$, of the large vegetative cell; $\times 600$.

Fig. I3. Cross-section of the wall of the ripe anther; $\times 600$.

Fig. I4. Germinating pollen-spore upon one of the stigmatlc papillae, $p ; \times 600$.

Fig. 15. Longitudinal section of a very young basal (long-ttyled) female flower; $\times 35^{\circ} ; 0$, the ovule.

Fig. 16. The ovole from a somewhat older flower; 0 , the apex; $\times 600$.

Fig. 17. Longitudinal section through a very young short-styled flower; car. the carpel; 0 , the ovale; $\times 600$.

Fig. 18. Longitadinal section of an ovale after the differentiation of the first integument, in.; $t$., the primary tapetal cell; $\times 600$.

\section{PLATE II.}

Fig. I9. Longitudinal section of young short-styled flower; $\times 6 \infty ; 0$, ovale; car., carpel.

Fig. 20. Longitudinal section of the young ovale, showing the beginning of the first integument, ir.; $\times 600$. 


\section{Campbell.-Development in Lilaea subulata.}

Fig. 21. An older ovule with the tapetum ( $t$.) already divided; in', first, in', second integument; $x 600$.

Fig. 22. A still older ovule. The lower cell of the axial row is becoming disorganized, and the one above it has two nuclei, but no division-wall has formed between the latter.

Fig. 23. The nucellus of an older ovale, showing the young embryo-sac with two nuclei; the section is cut somewhat obliquely; $m$, the remains of the upper archesporial cell.

Fig. 24. An older embryo-sac with eight naclei; $p, p^{1}$, the polar nuclei. The egg-nucleas lies immediately below the upper polar nucleus.

Fig. 25. Longitudinal aection of a flower with style of mediam length, showing the stigmatic papillae, st.; $\times 100$.

Fig. 26. Embryo-sac with egg-apparatus and antipodal cella fully formed, but the polar nuclet not yet united; only two antipodal cells show in the section; $x$ about 600 .

Fig. 27. Upper part of a fully developed embryo-sac; en, the endosperm-nucleus; $\times 650$.

Fig. 28. The antipodal end of the fully developed embryo-sac; $\times 650$.

Fig. 29. Two sections of an embryo-sac with a two-celled embryo; s, the remains of one of the synergide; $\times 300$.

Fig. 3o. Upper part of an abnormal embryo-sac. There were eight nuclei, two of which do not show in this section.

Figs. $3^{1-35}$. Successive stages in the development of the embryo, in longitudinal section; $\times 600$. The order of the transverse divisions is indicated by the lettering. The embryo shown in Fig. 33 had the terminal cell divided into four.

Fig. 36. A young embryo in which the second wall (2) in the terminal cell was oblique, instead of being formed at right angles to the first one.

Figs 37, 38. Two sections of an older embryo.

\section{PLATE III.}

Fig. 39. A somewhat advanced embryo, seen in median section, showing the enlarged suspensor-cell with its nucleus. The limits of the first transverse walls are still visible.

Fig. 40. A similar section of an older embryo, showing the first trace of the Stem-2pex, st., and the root, $r$.

Fig. 4r. A still older embryo, showing the strongly lateral position of the primary root, r.; st., stem-aper; cot., cotyledon.

Fig. 42. Section of an embryo from a nearly ripe seed; $\times 100$.

Fig. 43. The basal part of a similar embryo; $\times 35^{\circ}$.

Fig. 44. Three transverse sections of a young embryo; $\times 35^{\circ} ; a$ is a section just above the suspensor, and shows several of the endosperm-nuclei. 


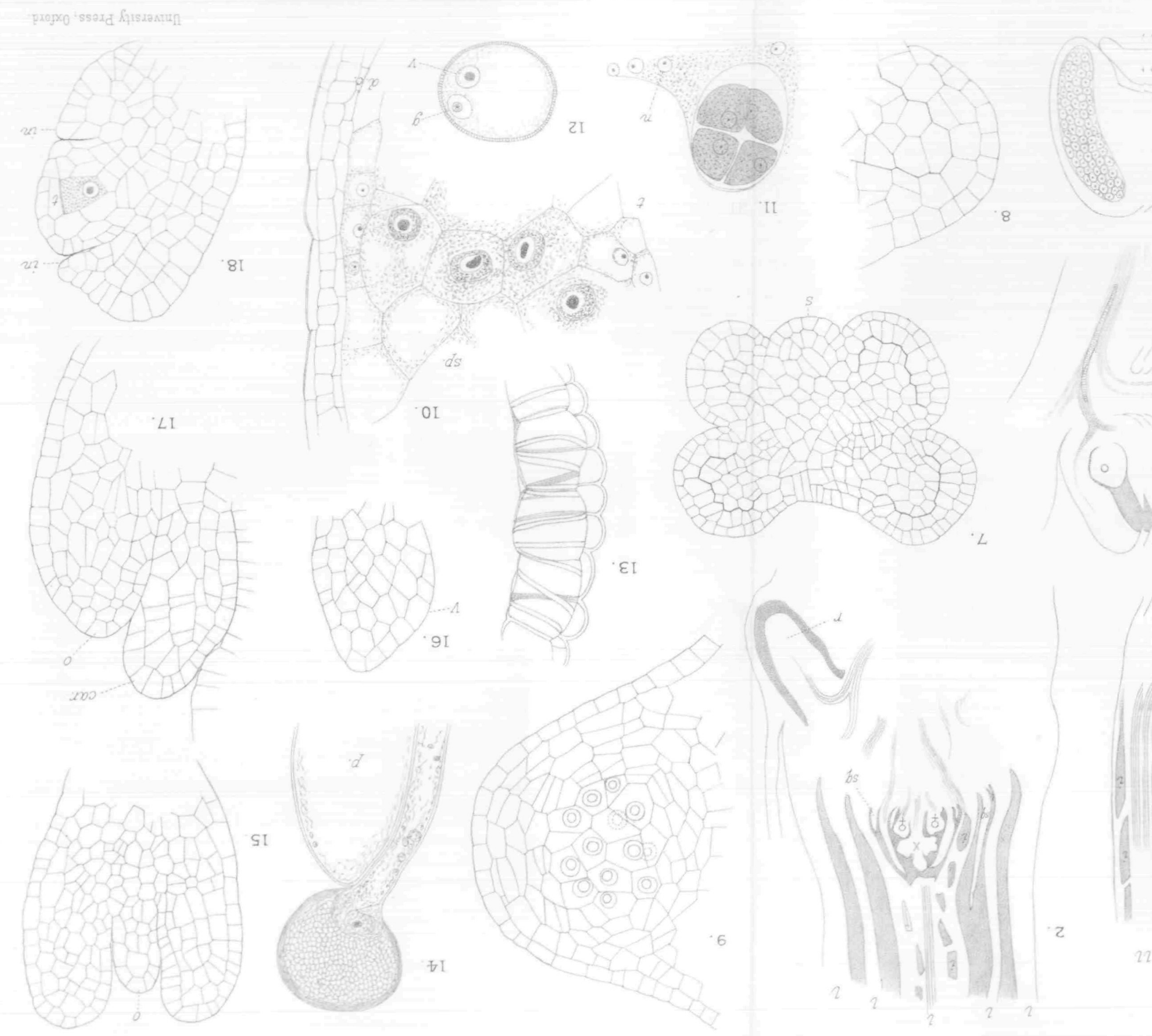

T'T' $I I X 7 \% A$ 
$\cdot$ 


\section{Annals of Botany}

$c a$
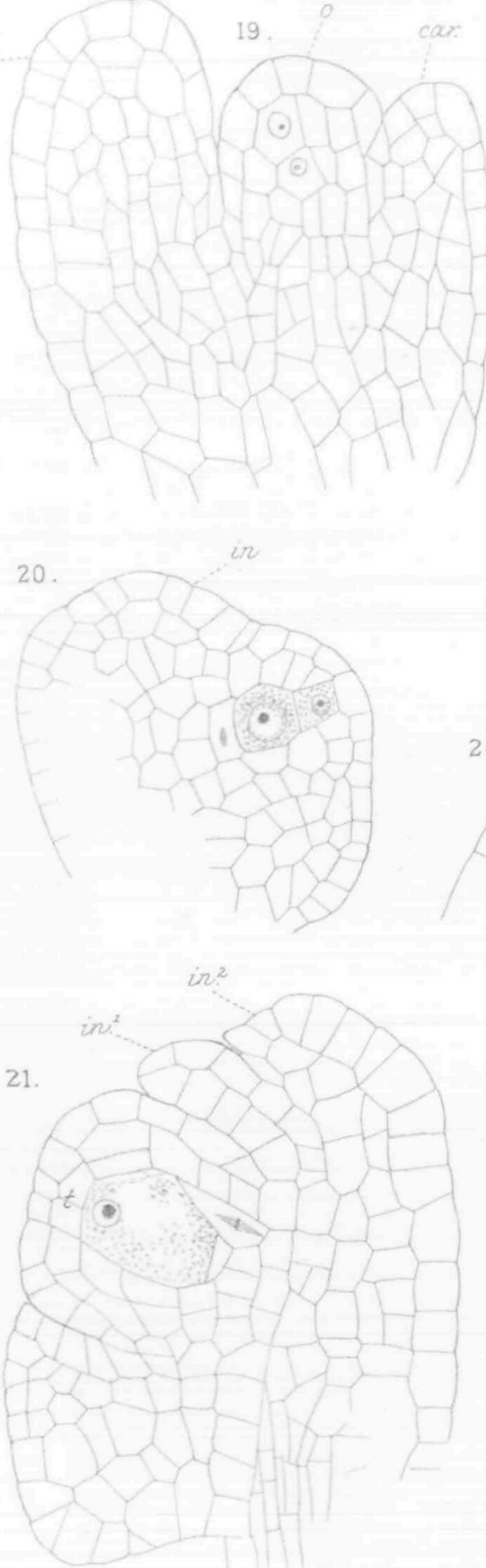

D.H.Campoell, del.

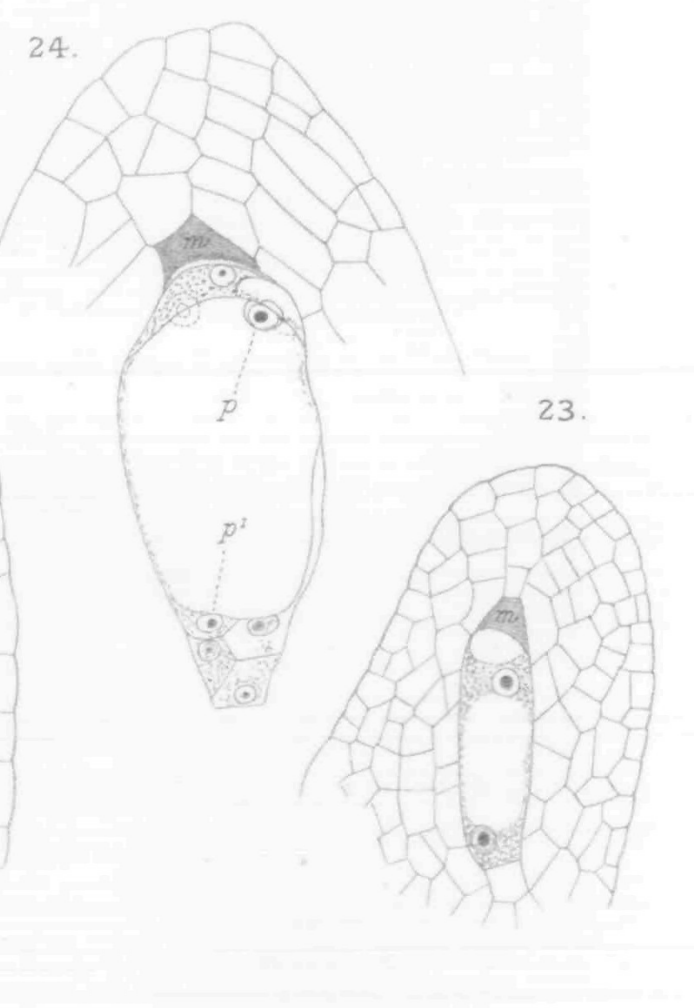

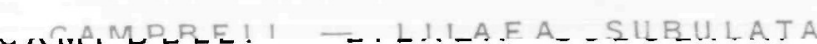
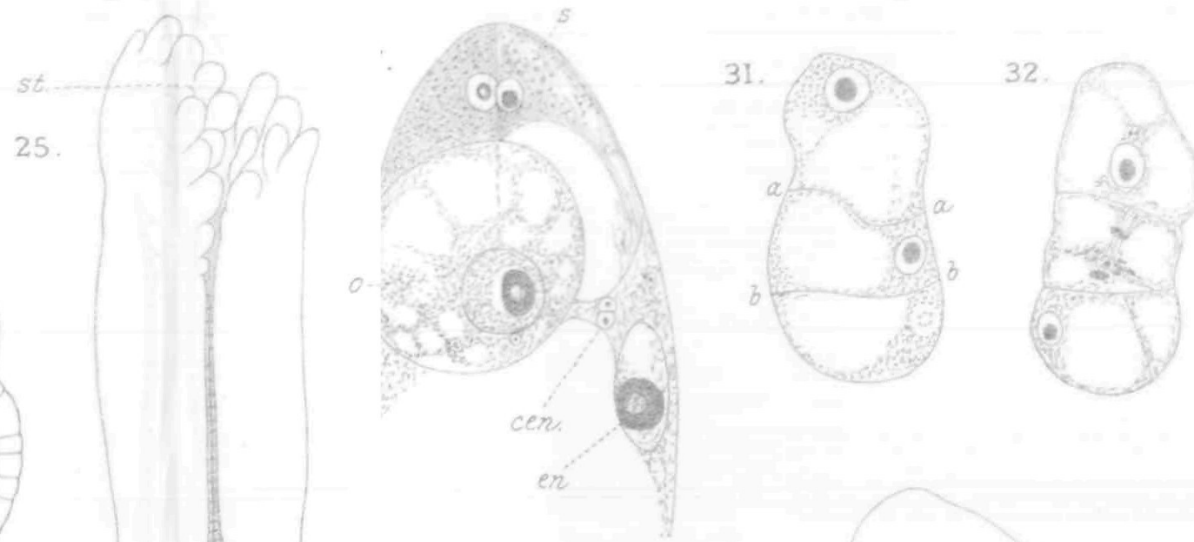

VoL.XII PZ.II.

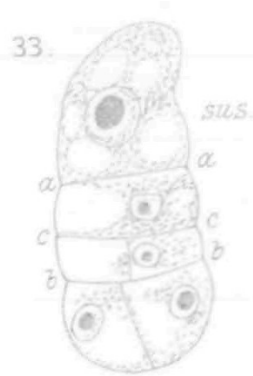

28
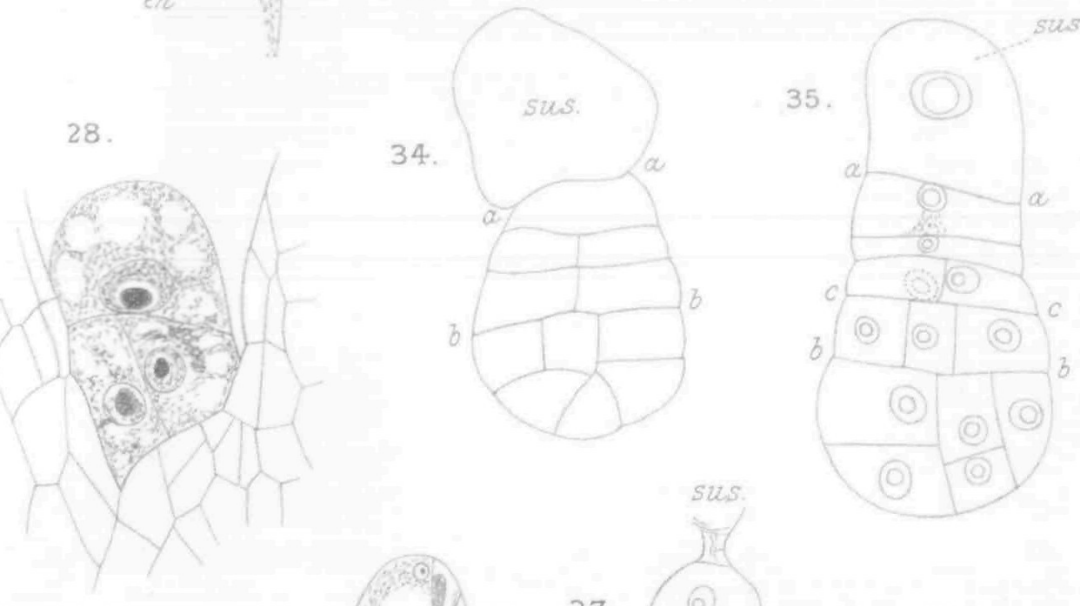

35.
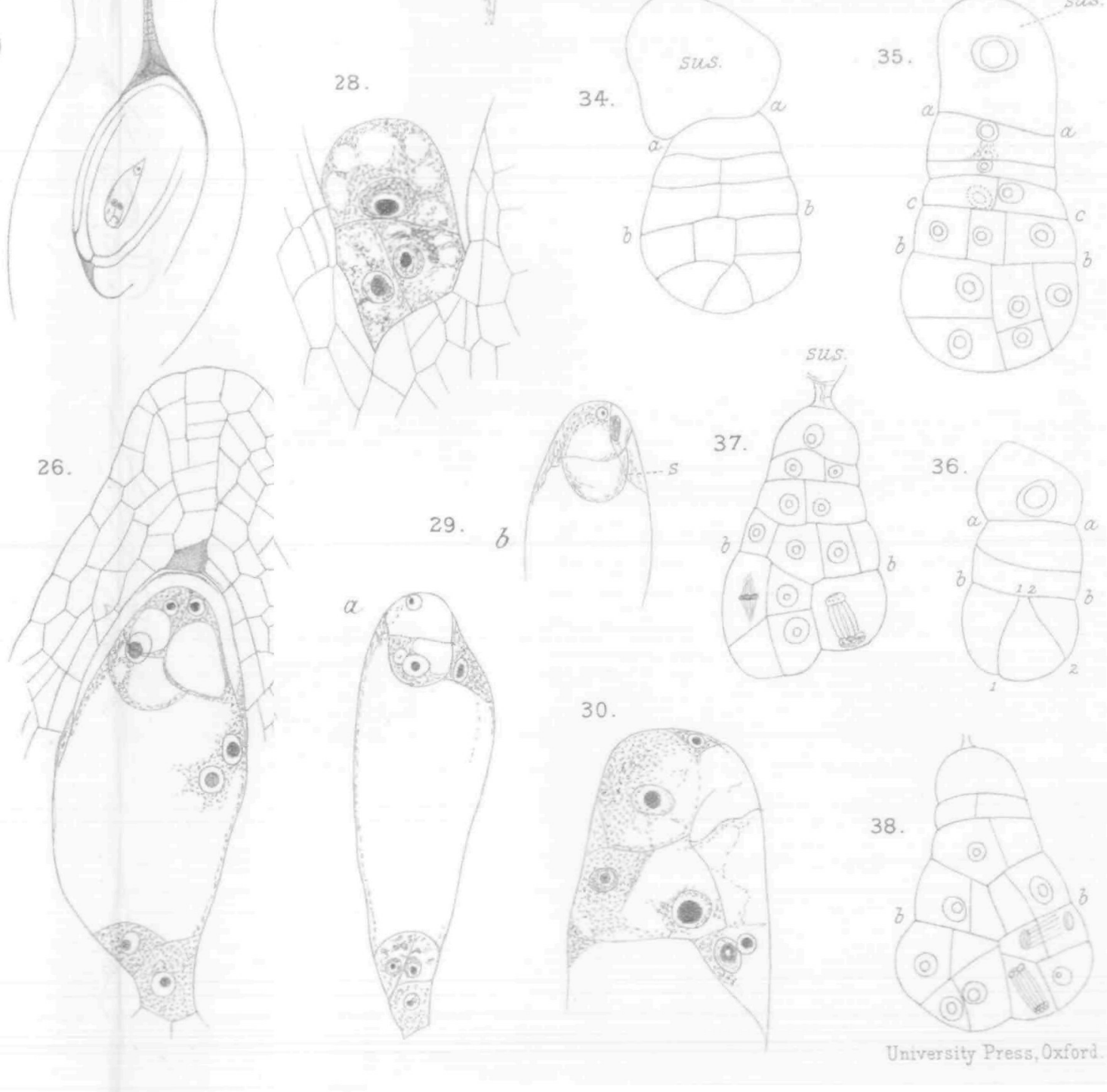

30
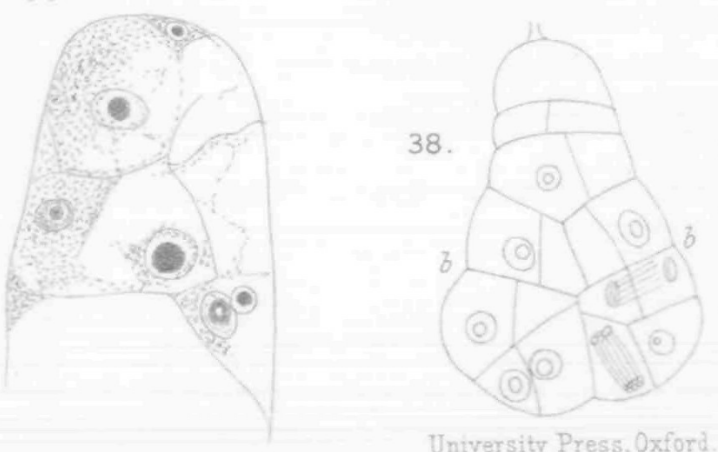

Annals of Botany

Vol XII PL III.
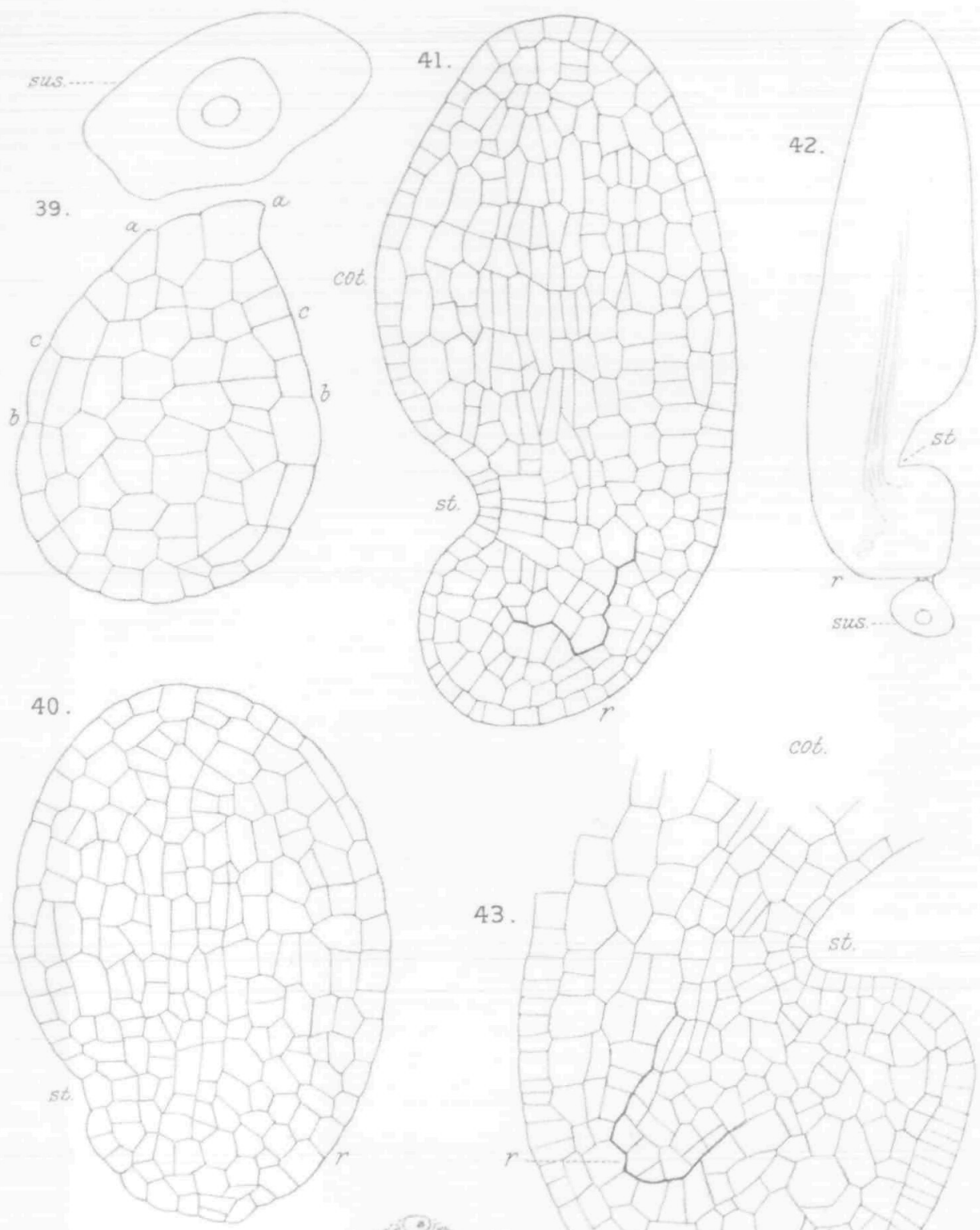

$\cot$.

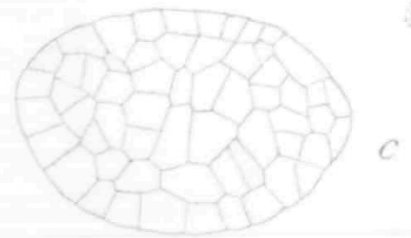

D.H. Campolli, del

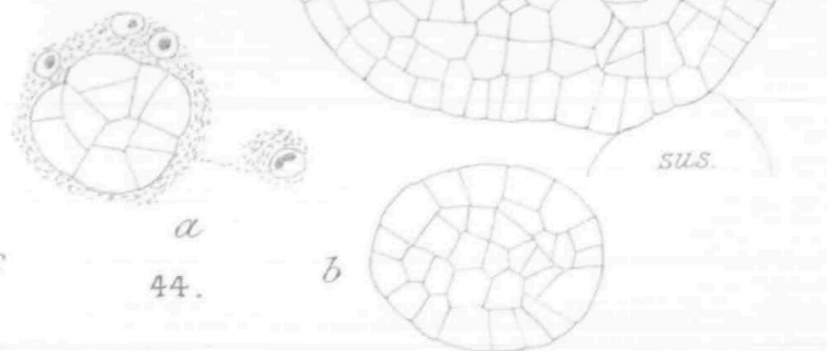

University Press, Oxford

CAMPBELL. - LILAEA SUBULATA. 
Downloaded from https://academic.oup.com/aob/article-abstract/os-12/1/1/233121

by Sussex Language Institute user

on 23 July 2018 